\title{
Calcium and magnesium do not alleviate the toxic effect of sodium on the emergence and initial growth of castor, cotton, and safflower
}

\author{
Liv S. Severino $^{a}$,*, Rosiane L.S. Lima ${ }^{b}$, Natalia Castillo ${ }^{c}$, Amanda M.A. Lucena $^{d}$, \\ Dick L. Auld ${ }^{\mathrm{e}}$, Theophilus K. Udeigwe ${ }^{\mathrm{e}}$ \\ a Embrapa Algodão, Rua Oswaldo Cruz, 1143, CEP 58428-095 Campina Grande, PB, Brazil \\ ${ }^{\mathrm{b}}$ Researcher PNPD/UFCG/CNPq, Universidade Federal de Campina Grande, Campina Grande, PB, Brazil \\ ${ }^{c}$ Department of Soil and Crop Science, Texas AEM Agrilife Research, Lubbock, TX 79403, USA \\ d Researcher PNPD/Embrapa/CNPq, Embrapa Algodão, Campina Grande, PB, Brazil \\ e Department of Plant and Soil Science, Texas Tech University, Lubbock, TX 79409, USA
}

\section{A R T I C L E I N F O}

\section{Article history:}

Received 12 November 2013

Received in revised form 3 March 2014

Accepted 18 March 2014

\section{Keywords:}

Ricinus communis

Gossypium hirsutum

Carthamus tinctorius

Salt stress

Alleviation

\begin{abstract}
A B S T R A C T
Castor (Ricinus communis), cotton (Gossypium hirsutum), and safflower (Carthamus tinctorius) are industrial crops frequently considered to be raised under high salinity of the soil or irrigation water. Sodium is the most common ion causing salinity, but other ions can also be found in toxic level. This experiment had the objective to evaluate if the presence of calcium and magnesium in the irrigation water alleviates the toxic effect of sodium in the emergence and initial growth of these three oilseed crops. Seeds were sown in trays for evaluation of emergence and in pots for evaluation of plant growth. The treatments consisted of simulations of the $\mathrm{Na}^{+}: \mathrm{Ca}^{2+}: \mathrm{Mg}^{2+}$ molar ratio found in the irrigation water of the Trans-Pecos region of the States of New Mexico and Texas, USA. The saline solutions were equivalent to 0, 50, 100, 150, 200, and $250 \%$ of the salt composition found in the reference water. Some solutions contained the three salts, while others contained only $\mathrm{Na}^{+}$, and the electrical conductivity varied from 0.7 to $13.7 \mathrm{dS} \mathrm{m}^{-1}$ among treatments. For the analysis of plant growth, the treatments were imposed after seedling emergence, and the plants were harvested after 30 days.

In castor and safflower, the salinity effect was associated with the electrical conductivity rather than with the salt composition. The cotton genotype had been previously selected to be tolerant to $\mathrm{Na}^{+}$, but it was sensitive to $\mathrm{Ca}^{2+}$ and $\mathrm{Mg}^{2+}$. Safflower plants did not survive 30 days under exposure to salinity higher than $9.6 \mathrm{dS} \mathrm{m}^{-1}$ with any salt composition. In conclusion, $\mathrm{Ca}^{+2}$ and $\mathrm{Mg}^{+2} \mathrm{did}$ not alleviate the toxic effect of $\mathrm{Na}^{+}$, and the mechanisms of salt tolerance in cotton were ion-specific.
\end{abstract}

(c) 2014 Elsevier B.V. All rights reserved.

\section{Introduction}

Salt stress is an important constraint for agricultural production in many regions of the globe. High soil salinity can arise from natural causes or from human intervention, particularly under irrigated agriculture (Munns and Tester, 2008). Salinity affects plant production through osmotic stress, specific-ion toxicity, and nutritional imbalances (Kopittke, 2012; Munns and Tester, 2008; Wakeel, 2013). There are large differences in the tolerance to salinity among

\footnotetext{
Abbreviations: EC, electrical conductivity.

* Corresponding author. Tel.: +55 8331824419.

E-mail addresses: liv.severino@embrapa.br (L.S. Severino),

limarosiane@yahoo.com.br (R.L.S. Lima), sarrafcastillo@gmail.com (N. Castillo), amandamicheline@hotmail.com (A.M.A. Lucena), dick.auld@ttu.edu (D.L. Auld), theo.udeigwe@ttu.edu (T.K. Udeigwe).
}

species because many mechanisms are used to protect vital organs and to exclude or compartmentalize salts.

Salts interfere with plant growth through two processes: initially, the growth slows due to osmotic stress, as the water uptake by root is impaired; later, the salts accumulate in toxic concentration in old leaves and cause its death (Munns and Tester, 2008). When initially exposed to high salt content, plant growth rapidly reduces due to osmotic (non-specific) effects. Over longer periods (days to weeks), individual salts may accumulate to toxic levels, thereby inducing specific-ion toxicities (Munns, 2002).

The most frequent salts affecting crops worldwide are $\mathrm{Na}^{+}$and $\mathrm{Cl}^{-}$, but salinity can also be caused by $\mathrm{K}^{+}, \mathrm{Ca}^{2+}$, and $\mathrm{Mg}^{2+}$, and to a lesser extent by sulfates and carbonates. The toxicity caused by $\mathrm{Na}^{+}$ can be alleviated by other cations, such as $\mathrm{K}^{+}, \mathrm{Ca}^{2+}$, and $\mathrm{Mg}^{2+}$. However, these cations have complex interactions in which $\mathrm{K}^{+}$seems to be the most important antagonist of $\mathrm{Na}^{+}$, but it depends on the presence of $\mathrm{Ca}^{2+}$ or $\mathrm{Mg}^{2+}$ to be effective. In some situations, $\mathrm{Ca}^{2+}$ 
Table 1

Description of the concentration of each ion and the electrical conductivity of the saline solutions.

\begin{tabular}{|c|c|c|c|c|}
\hline Salt composition & $\begin{array}{l}\mathrm{NaCl} \\
(\mathrm{mMol})\end{array}$ & $\begin{array}{l}\mathrm{CaSO}_{4} \\
(\mathrm{mMol})\end{array}$ & $\begin{array}{l}\mathrm{MgSO}_{4} \\
(\mathrm{mMol})\end{array}$ & 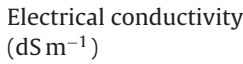 \\
\hline \multirow[t]{8}{*}{ Control } & - & - & - & 0.7 \\
\hline & 18 & - & - & 1.8 \\
\hline & 36 & - & - & 3.9 \\
\hline & 54 & - & - & 4.8 \\
\hline & 71 & - & - & 6.1 \\
\hline & 89 & - & - & 7.7 \\
\hline & 18 & 11 & 6 & 3.6 \\
\hline & 36 & 22 & 12 & 7.9 \\
\hline \multirow[t]{3}{*}{$\mathrm{Na}^{2+}, \mathrm{Ca}^{2+}$, and $\mathrm{Mg}^{2+}$} & 54 & 33 & 17 & 9.6 \\
\hline & 71 & 43 & 23 & 12.8 \\
\hline & 89 & 54 & 29 & 13.7 \\
\hline
\end{tabular}

has an apparent $\mathrm{Na}^{+}$-alleviation effect, but this effect is still questionable, and the alleviation is observed in the cell uptake of $\mathrm{Na}^{+}$ rather than in the growth reduction caused by this ion. Increased $\mathrm{Na}^{+}, \mathrm{K}^{+}$, and $\mathrm{Mg}^{2+}$ concentrations can reduce $\mathrm{Ca}^{2+}$ activity in the plasma membrane and induce deficiency of this nutrient (Kopittke et al., 2011; Kopittke, 2012; Munns and Tester, 2008; Tester and Davenport, 2003; Wakeel, 2013).

Castor (Ricinus communis L.), cotton (Gossypium hirsutum L.), and safflower (Carthamus tinctorius L.) are industrial oilseed crops that are often considered for cultivation in salt affected areas (Costa et al., 2013; Li et al., 2010b; Nobre et al., 2013; Silva et al., 2005; Tiwari et al., 2013; Yeilaghi et al., 2012). If their tolerance to salt stress is confirmed, these crops will be interesting options for regions where agricultural production suffers with this limiting factor.

The objective of this study was to evaluate if the presence of the cations $\mathrm{Ca}^{2+}$ and $\mathrm{Mg}^{2+}$ in the irrigation water alleviates the toxic effect of $\mathrm{Na}^{+}$on seedling emergence and initial growth of castor, cotton, and safflower plants.

\section{Material and methods}

The experiments were conducted in a greenhouse at Texas Tech University (Lubbock, TX, USA) in 2012. The treatments were designed as a simulation of the concentrations and proportions of major salts found in the irrigation water in the Trans-Pecos region in the State of Texas, USA (Ashworth, 1995). The treatments were defined as $50,100,150,200$, and $250 \%$ of the reference water, which had 36,26 , and $12 \mathrm{mM}$ of $\mathrm{Na}^{+}, \mathrm{Ca}^{+2}$, and $\mathrm{Mg}^{+2}$, respectively. The molar ratio was $1 \mathrm{Na}^{+}: 0.72 \mathrm{Ca}^{2+}: 0.33 \mathrm{Mg}^{2+}$. The same treatments were then repeated without inclusion of $\mathrm{Ca}^{2+}$ and $\mathrm{Mg}^{2+}$ (Table 1).

Saline solutions were prepared in 120-L plastic containers mixing tap water $\left(0.004 \mathrm{dS} \mathrm{m}^{-1}\right)$ with $\mathrm{NaCl}, \mathrm{CaSO}_{4}$, and $\mathrm{MgSO}_{4}$ in amounts to reach the assigned treatment (Table 1). A soluble fertilizer was mixed in equal dose to all the solutions in order to add $18 \mathrm{mM}$ of $\mathrm{N}, 2 \mathrm{mM}$ of $\mathrm{P}$, and $4 \mathrm{mM}$ of $\mathrm{K}$. The control treatment was tap water with addition of the fertilizer. Because the $\mathrm{K}^{+}$concentration was fixed (because it was supplied as fertilizer), the molar ratio $\mathrm{Na}^{+}: \mathrm{K}^{+}$among the solutions varied from $1: 0.04$ to $1: 0.22$. The electrical conductivity (EC) was measured after the solutions were prepared, and it varied from 0.7 to $13.7 \mathrm{dS} \mathrm{m}^{-1}$ (Table 1 ). This solution was used for the experiments of seedling emergence and plant growth.

Studies on salinity should be preferentially based on the osmotic potential of the solutions rather than on the EC. However, EC has been used in most experiments with salinity because it is closely related to the osmolarity, and it is easier to measure (Ben-Gal et al., 2009). A correlation of 0.94 was found between the osmotic potential (varying from -0.029 to $-0.485 \mathrm{MPa}$ ) and the electrical conductivity (varying from 0.40 to $14.35 \mathrm{dS} \mathrm{m}^{-1}$ ) in solutions with varying contents of $\mathrm{Na}$ and $\mathrm{Ca}$ (Ben-Gal et al., 2009).

The study was conducted with castor seeds of the cv. Brigham, which is the first commercial variety selected for reduced ricin content (Auld et al., 2003), cotton line DN-1, which was previously selected for tolerance to high $\mathrm{NaCl}$ among wild cotton accesses in a hydroponic system (Castillo, 2011), and safflower line 672, which was selected for winter planting in the breeding program of Texas Tech University (Oswalt and Auld, 2011).

\subsection{Seedling emergence}

Plastic trays were filled with an 8-cm layer of the substrate Metromix $^{\circledR}$ (vermiculite, bark, peat moss, and coarse perlite). The test in castor was made with four replications of 40 seeds per tray, and in safflower, it was made with nine replications of 20 seeds. The seedling emergence was not tested in cotton. Trays were arranged in a completely randomized design. Seeds were buried 3-cm deep (castor) or 1-cm deep (safflower), covered with substrate, and irrigated daily with the respective saline solution. Emerged seedlings were counted daily and discarded (clipped). They were assumed as emerged when the cotyledons were out of the soil.

After sowing, data was taken over 20 days in castor and 9 days in safflower. The percentage of emergence and the time for emergence of $50 \%$ of the seeds were calculated. The time for $50 \%$ of emergence of castor seedlings was calculated by interpolation in order to include the fraction of day. The equation was $t_{50 \%}=t_{d-1}+\left(50-e_{d-1}\right) /\left(e_{d}-e_{d-1}\right)$, in which $t_{50 \%}$ is the time for emergence of $50 \%$ of the seeds, $t_{d-1}$ is the day before $50 \%$ was reached, $e_{d-1}$ is the emergence (\%) observed in $t_{d-1}$, and $e_{d}$ is the emergence (\%) in the day it was $\geq 50 \%$. In safflower, the same calculation was made considering the threshold of $40 \%$, because some plots did not reach $50 \%$ of emergence.

\subsection{Plant growth}

The experiment was conducted in $12-\mathrm{L}$ pots in a greenhouse with controlled temperature $\left(28 \pm 3^{\circ} \mathrm{C}\right)$. The substrate was made of soil from the top soil layer $(0-15 \mathrm{~cm})$ collected from the Experimental Farm of Texas Tech University (Lubbock, TX). The soil had $2500 \mathrm{mg} \mathrm{kg}^{-1}$ of $\mathrm{Ca}^{2+}$ and $520 \mathrm{mg} \mathrm{kg}^{-1}$ of $\mathrm{K}^{+}$. The pots of the same species were arranged in a completely randomized design with four replications. Five seeds were sowed in each pot, and irrigated with tap water. The salt treatments begun immediately after the first seedling emerged. The pot was daily irrigated with the respective saline solution in a volume enough for allowing at least $20 \%$ of drainage. Ben-Gal et al. (2009) employed a similar method (daily irrigation with $20 \%$ drainage) and confirmed that the technique worked properly because the salinity in the drainage water was stable, and the $\mathrm{Na}^{+}$and $\mathrm{Ca}^{2+}$ content were always proportional (twice) to the amounts added through irrigation.

Destructive analyses were conducted at 30 days after emergence. The reproductive structures (flowers, racemes) and dead plants were counted. Leaf area was measured twice using a Li-Cor LI-3100 m. Roots were carefully washed from the soil. Dry weight of leaves, stems, and roots were taken after oven-drying for three days at $80^{\circ} \mathrm{C}$. Shoot/root ratio was calculated.

\subsection{Statistical analysis}

The data on castor and cotton (all cations) was analyzed by polynomial regression using the linear model $(y=a x+b)$ in function of the EC of the irrigation water. The data on safflower and cotton $\left(\mathrm{Na}^{+}\right)$plant growth was analyzed using the model of inverse first order $(y=a / x+b)$. The slope significance in both models was tested with $t$ test $(p<0.05)$. Equations were calculated separately for the 


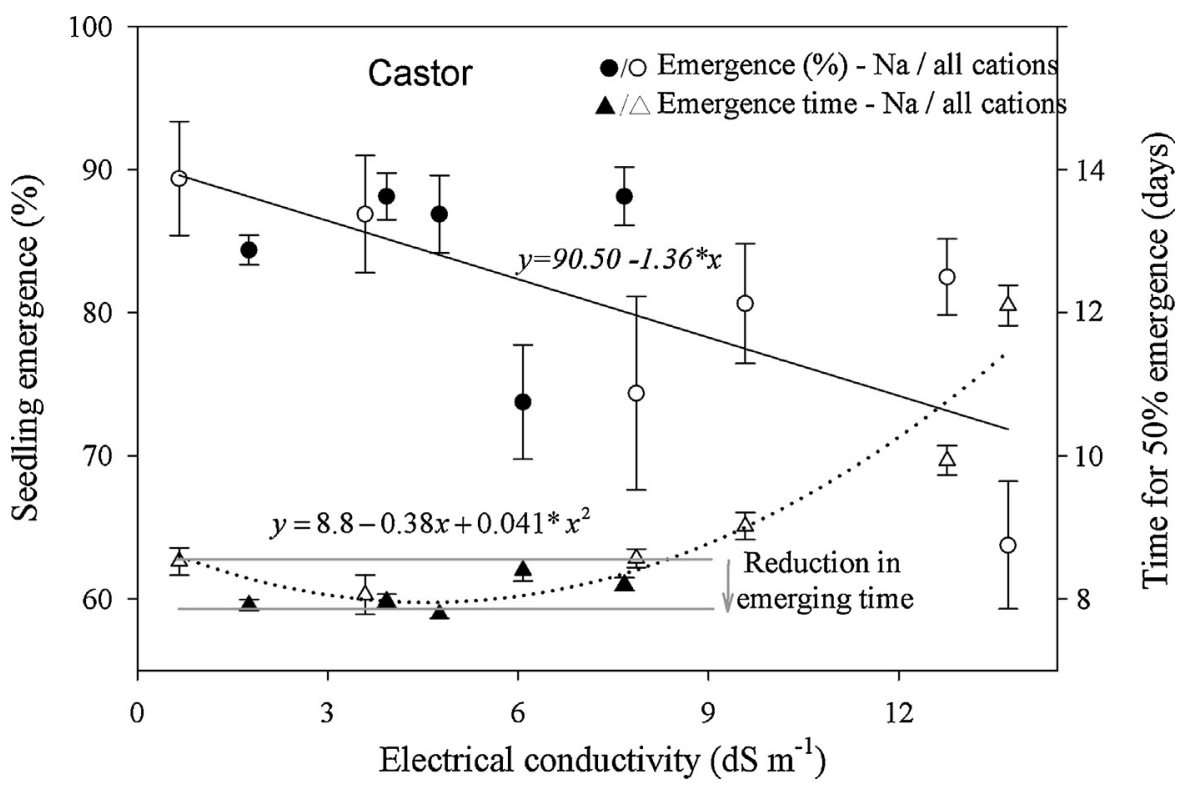

Fig. 1. Effect of the electrical conductivity of irrigation water containing combinations of $\mathrm{Na}^{+}, \mathrm{Ca}^{2+}$, and $\mathrm{Mg}^{2+}$ on the emergence of castor seedlings.

treatments with and without $\mathrm{Ca}^{2+}$ and $\mathrm{Mg}^{2+}$, and the slopes were compared by $F$ test (Graybill, 1976). The data obtained in the control treatment was considered for both equations. The equations were presented in the graphs, and the line was omitted when the regression analysis ( $F$ test) was not significant.

\section{Results}

\subsection{Seedling emergence}

The effect of water salinity on seedling emergence was poorly explained by the salt composition, but it was closely associated with the EC of the irrigation water. The saline solution containing only $\mathrm{Na}^{+}$did not influence castor seedling emergence rate (Fig. 1). When $\mathrm{Ca}^{2+}$ and $\mathrm{Mg}^{2+}$ were included, the EC reached $13.7 \mathrm{dS} \mathrm{m}^{-1}$, and the emergence rate was linearly reduced. The castor seedling emergence occurred slightly faster when the EC was around $5 \mathrm{dS} \mathrm{m}^{-1}$, than in the control treatment. The estimated time for $50 \%$ emergence of castor seedling was reduced by 0.58 days in the salinity of $5 \mathrm{dS} \mathrm{m}^{-1}$ (all cations, Fig. 1). In the saline solution of $4.8 \mathrm{dS} \mathrm{m}^{-1}$ (only $\mathrm{Na}^{+}$), the time for emergence was significantly $(p=0.02$ ) reduced by 0.7 days in comparison with the control ( 8.5 days). The emergence rate and the time for $40 \%$ emergence of safflower seedlings were not influenced by salinity of water even in the highest EC tested (Table 3).

\subsection{Plant growth}

The reduction in leaf area and accumulated biomass (shoot and root dry weight) of castor plants was related to the EC of irrigation water rather than to the presence or absence of $\mathrm{Ca}^{2+}$ and $\mathrm{Mg}^{2+}$. In castor, the slopes of the lines of $\mathrm{Na}^{+}$and all cations were equal in the three growth characteristics considered (Fig. 2). Comparing the control treatment $\left(0.7 \mathrm{dS} \mathrm{m}^{-1}\right)$ with the highest EC treatment $\left(13.7 \mathrm{dS} \mathrm{m}^{-1}\right)$, the leaf area was reduced from 3607 to $445 \mathrm{~cm}^{2}(12 \%$ of the control), the shoot dry weight was reduced from 30.2 to 5.5 ( $18 \%$ of the control), and the root dry weight was reduced from 4.1 to $0.46 \mathrm{~g}$ ( $11 \%$ of the control). The shoot/root ratio in castor plants was not affected by salinity because both components were reduced in the same proportion (Table 2 ). The initiation of reproductive structures at 30 days after emergence was not influenced by isolated $\mathrm{Na}^{+}$, but it was linearly reduced by the saline solutions including all the cations. All castor plants survived 30 days under the salinity treatments.

Reflecting the selection for $\mathrm{NaCl}$ tolerance that resulted in the line DN-1 (Castillo, 2011), the effect of salinity on cotton was dependent on the salt composition. The cotton plants exposed only to $\mathrm{Na}^{+}$had the leaf area reduced from $1324 \mathrm{~cm}^{2}$ in the control treatment to a stable area of approximately $750 \mathrm{~cm}^{2}(57 \%$ of the control) in the range of salinity varying between 1.8 and $7.7 \mathrm{dS} \mathrm{m}^{-1}$ (Fig. 3). Similarly, the shoot dry weight was reduced from $9.3 \mathrm{~g}$ in the control treatment to around $6 \mathrm{~g}$ (65\% of the control) regardless of $\mathrm{Na}^{+}$content. It seems that cotton plants were able to tolerate the increased content of $\mathrm{Na}^{+}$with little reduction in the leaf area growth and biomass accumulation. Nevertheless, when the saline solution contained the three cations, the leaf area and the shoot biomass were linearly reduced with increasing EC (Fig. 3). The leaf area was reduced from $1547 \mathrm{~cm}^{2}$ in the control treatment to $198 \mathrm{~cm}^{2}$ in the highest salinity (13\% of the control). The shoot dry weight was reduced from $10.5 \mathrm{~g}$ in the control treatment to $1.8 \mathrm{~g}$ in the highest salinity ( $16 \%$ of the control).

The cotton root dry weight was not significantly influenced by the water salinity (Fig. 3). The effect of the salinity caused by the three cations was not significant because there was an outlier point (when the EC was $3.6 \mathrm{dS} \mathrm{m}^{-1}$ ). Excluding that point from the curve, a significant linear reduction $(p=0.015)$ of the root dry weight was found. The root dry weight was reduced from $1.23 \mathrm{~g}$ in the control to $0.40 \mathrm{~g}$ in the highest EC (observed values). The shoot/root ratio was linearly reduced by the increasing salinity (Table 2 ). The reduction in growth was more intense in the shoot than in the root of cotton plants, what is generally observed in most non-halophyte species (Munns and Tester, 2008). The reduction in shoot/root ratio in response to salt stress is even more pronounced in salt-tolerant cotton plants (Saleh, 2012). There was no influence of salinity on the number of reproductive structures and no cotton plant died after being exposed for 30 days to salt stress (Table 2).

All the growth characteristics evaluated in safflower plants, leaf area, shoot, and root growth, were affected in the same manner. These characteristics were sharply reduced between 0.7 and $2 \mathrm{dS} \mathrm{m}^{-1}$, but little affected between 3 and $9 \mathrm{dS} \mathrm{m}^{-1}$ (Fig. 4). The leaf area was $665 \mathrm{~cm}^{2}$ in the control treatment and was reduced to the range of 175 to $250 \mathrm{~cm}^{2}$ ( 26 to $38 \%$ of the control treatment) 
Table 2

Influence of the salinity on the number of reproductive structures and the shoot/root ratio of castor, cotton, and safflower plants at 30 days after emergence.

\begin{tabular}{|c|c|c|c|c|c|}
\hline \multicolumn{3}{|c|}{$\mathrm{Na}^{+}$} & \multicolumn{3}{|c|}{$\mathrm{Na}^{+}, \mathrm{Ca}^{2+}$, and $\mathrm{Mg}^{2+}$} \\
\hline Electrical conductivity $\left(\mathrm{dS} \mathrm{m}^{-1}\right)$ & Reproductive structures & Shoot/root ratio & Electrical conductivity $\left(\mathrm{dS} \mathrm{m}^{-1}\right)$ & Reproductive structures & Shoot/root ratio \\
\hline \multicolumn{6}{|l|}{ Castor } \\
\hline 0.7 & 1.5 & 7.78 & 0.7 & 1.50 & 7.78 \\
\hline 1.8 & 1.5 & 6.37 & 3.6 & 1.75 & 7.23 \\
\hline 3.9 & 1.5 & 7.02 & 7.9 & 1.50 & 9.89 \\
\hline 4.8 & 1.0 & 6.55 & 9.6 & 0.75 & 10.39 \\
\hline 6.1 & 1.0 & 7.44 & 12.8 & 0.75 & 8.81 \\
\hline 7.7 & 1.0 & 8.41 & 13.7 & 0.50 & 7.58 \\
\hline Regression equation & $y=1.61-0.09^{n s} x$ & $y=6.74-0.13^{n s} x$ & & $y=1.83-0.88 \times x$ & $y=8.01-0.08^{n s} x$ \\
\hline \multicolumn{6}{|l|}{ Cotton } \\
\hline 0.7 & 2.5 & 9.82 & 0.7 & 2.5 & 9.82 \\
\hline 1.8 & 1.5 & 11.54 & 3.6 & 3.3 & 3.70 \\
\hline 3.9 & 1.3 & 4.92 & 7.9 & 1.5 & 6.39 \\
\hline 4.8 & 2.5 & 4.81 & 9.6 & 1.0 & 8.45 \\
\hline 6.1 & 1.0 & 5.03 & 12.8 & 0.5 & 9.30 \\
\hline 7.7 & 2.0 & 7.42 & 13.7 & 0.0 & 4.11 \\
\hline Regression equation & $y=2.03-0.06^{n s} x$ & $y=10.1-0.69 \times x$ & & $y=3.24-0.22 \times x$ & $y=7.53-0.07^{n s} x$ \\
\hline \multicolumn{6}{|l|}{ Safflower } \\
\hline 0.7 & 5.8 & 7.76 & 0.7 & 5.8 & 7.76 \\
\hline 1.8 & 5.8 & 7.33 & 3.6 & 5.5 & 5.97 \\
\hline 3.9 & 3.5 & 7.19 & 7.9 & 4.3 & 10.43 \\
\hline 4.8 & 3.8 & 7.09 & 9.6 & 2.8 & 5.29 \\
\hline 6.1 & 3.8 & 5.79 & - & - & - \\
\hline 7.7 & 2.8 & 4.75 & - & - & - \\
\hline Regression equation & $y=6.03-0.44 \times x$ & $y=6.5+0.05^{n s} x$ & & $y=6.29-0.32 \times x$ & $y=7.43-0.052-$ \\
\hline
\end{tabular}

between the salinity varying from 3 to $9 \mathrm{dS} \mathrm{m}^{-1}$. The shoot dry weight was reduced from $8.4 \mathrm{~g}$ in the control treatment to around $3.0 \mathrm{~g}$ ( $36 \%$ of the control) in those intermediate salinity treatments. The root dry weight was reduced from $1.1 \mathrm{~g}$ in the control treatment to around $0.53 \mathrm{~g}$ ( $48 \%$ of the control) in the salinity between 3.9 and $9.6 \mathrm{dS} \mathrm{m}^{-1}$ (Fig. 4). The shoot/root ratio of safflower plants was not influenced by salinity treatments (Table 2). The number of reproductive structures was linearly reduced regardless of salt composition. The average of 5.8 flowers per plant in the control treatment was reduced to 2.8 flowers per plant under both $7.7 \mathrm{dS} \mathrm{m}^{-1}$ with $\mathrm{Na}^{+}$and $9.6 \mathrm{dS} \mathrm{m}^{-1}$ with all cations (Table 2).

Safflower plants did not survive 30 days exposed to salinity greater than $9.6 \mathrm{dS} \mathrm{m}^{-1}$. After a few weeks of exposure to the lethal levels of salinity, the plants still showed leaves with appearance similar to the plants exposed to medium salinity $\left(3-9 \mathrm{dS} \mathrm{m}^{-1}\right)$. However, those plants died suddenly without intensification of the symptoms of salt toxicity.

\section{Discussion}

\subsection{Effect of salt stress on plant growth}

The typical symptoms of salt-stress were observed in the three species evaluated in this study. However, the response to the increased salinity and to the salt composition was different for each species. The plants were subjected to the stress when they were predominantly in the phase of osmotic adjustment, but some characteristics of the phase of ionic toxicity were also noticed. In general, the main effect of salt stress on plants is the reduction in the size and number of leaves, and shoot growth, while roots tend to be less sensitive (Kopittke et al., 2011; Munns and Tester, 2008). Some responses to salinity can be observed a few minutes after the plant is exposed to the stress. After the initial exposure, the plant performs an osmotic adjustment that provides the tolerance to the stress in long exposure time (weeks to months). After weeks of exposure, the cations build up more intensively in the roots, but also in leaves and stems. The leaves senescence occurs when salts accumulate to a toxic level, but accumulation in roots and stems will eventually cause plant death. Salts can also affect plant growth due to nutritional imbalances (Grattan and Grieve, 1999; Plaza et al., 2012).

\subsection{Castor}

The response of castor plant growth to salinity was linear, without an apparent tolerance level, and independent of the salt composition (Fig. 2). The sensitivity of castor to salinity (particularly to $\mathrm{NaCl}$ ) is well documented in the scientific literature, and this oilseed crop is considered a sensitive species (Li et al., 2010a; Nobre et al., 2013; Pinheiro et al., 2008; Severino et al., 2012a, 2012b; Silva et al., 2005, 2008; Sun et al., 2013; Zhou et al., 2010). $\mathrm{Na}^{+}$typically slows the seedling emergence and reduces plant growth and photosynthetic metabolism (Pinheiro et al., 2008; Silva et al., 2005; Zhou et al., 2010). However, there are large differences among varieties in the response to salt stress. Sun et al. (2013) observed that the cv. Memphis showed the slowest emergence, but its seed yield was the least affected by salinity (compared with other five varieties). Silva et al. (2005) observed that the variety CSRN-367 was less sensitive to $\mathrm{NaCl}$ than the $\mathrm{cv}$. BRS Paraguaçu. The sensitivity of castor plants to salt stress was not different among developmental stages (Costa et al., 2013).

The slight increase in the speed of castor seedling emergence under mild salinity observed in this study (Fig. 1) was also observed in studies with castor cVs. Memphis and BRS Energia (Nobre et al., 2013; Silva et al., 2005; Sun et al., 2013) and as result of increased electrical conductivity caused by the addition of $\mathrm{Ca}^{+2}$ (Joshi et al., 2012). However, this effect was not observed or commented in most reports (Li et al., 2010a; Severino et al., 2012b; Zhou et al., 2010). It is not clear why a weak salinity promotes a faster seedling emergence, but two hypotheses are proposed: (i) the salt solution caused a kind of seed priming effect, in which the seed is exposed to a controlled salinity or osmotic solution before sowing in order to reduce unevenness of germination and emergence (Ashraf and Foolad, 2005; Rahimi, 2013); (ii) the salts changed the water permeability of the seed coat and promoted a faster hydration of the 

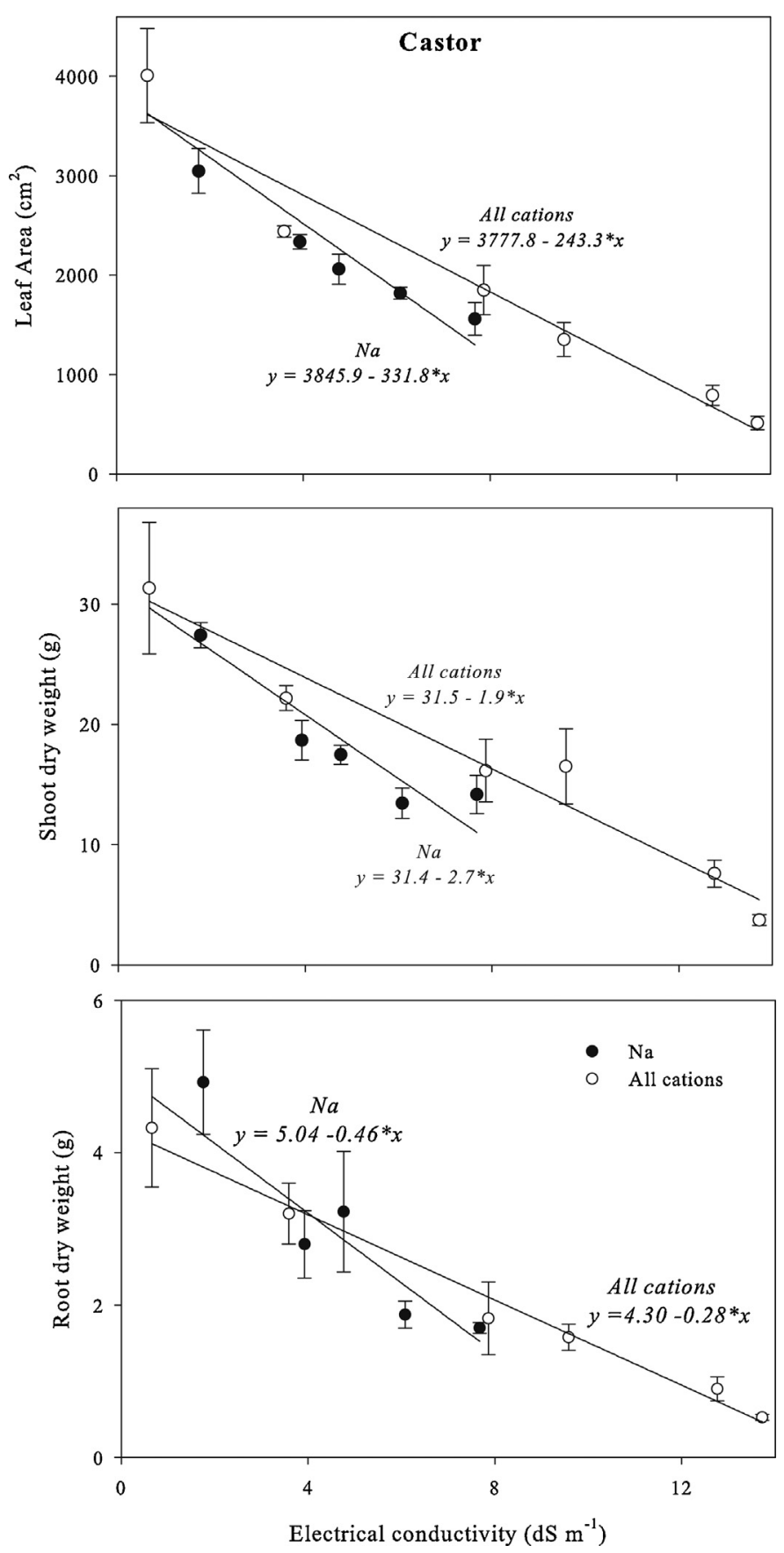

Fig. 2. Effect of the electrical conductivity of the irrigation water containing combinations of $\mathrm{Na}^{+}, \mathrm{Ca}^{2+}$, and $\mathrm{Mg}^{2+}$ on the leaf area, and shoot and root dry weight of 30-days old castor plants.

embryo and endosperm. These hypotheses need to be further investigated.

\subsection{Cotton}

Cotton is regarded as moderately tolerant to salt stress (Dong, 2012; Leidi and Saiz, 1997; Munns, 2002; Munns and Tester, 2008; Shaheen et al., 2012; Tiwari et al., 2013). The line DN-1 was selected to be tolerant to $\mathrm{Na}^{+}$but not to high concentrations of $\mathrm{Ca}^{2+}$ or $\mathrm{Mg}^{2+}$. Usually, the tolerance to salinity is specific to one salt because the dynamics of cations in the plant is mediated by ion-specific mechanisms (transporters, channels) (Wakeel, 2013).
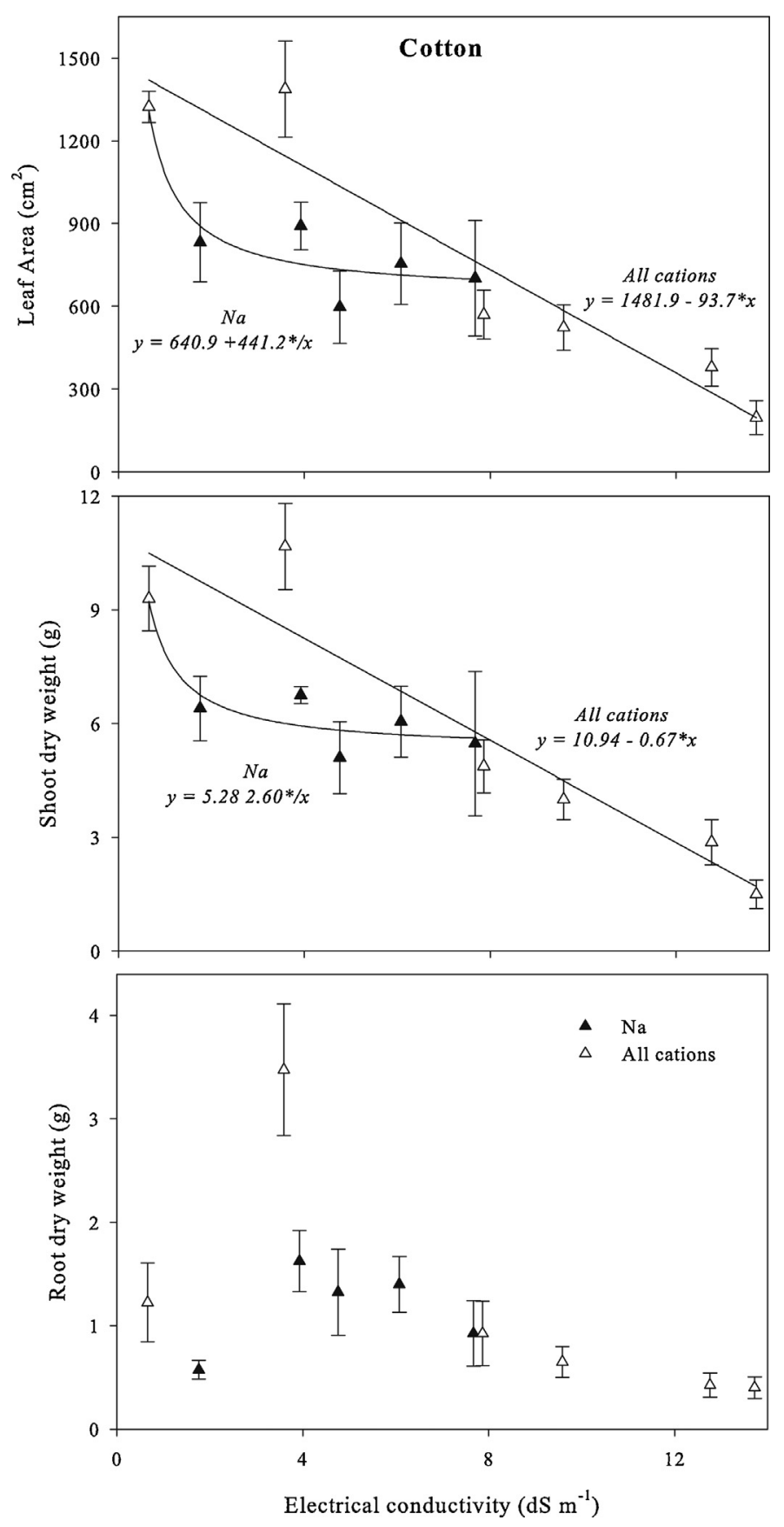

Fig. 3. Effect of the electrical conductivity of the irrigation water containing combinations of $\mathrm{Na}^{+}, \mathrm{Ca}^{2+}$, and $\mathrm{Mg}^{2+}$ on the leaf area, and shoot and root dry weight of 30-days old cotton plants.

The results of this study are evidence that the mechanisms of tolerance in cotton line $\mathrm{DN}-1$ were ion-specific. The cotton plant had efficient mechanisms to sustain growth after being exposed to toxic $\mathrm{Na}^{+}$concentrations. The mechanisms of tolerance supported a stable rate of plant growth in a range of salinities (roughly between 2 and $8 \mathrm{dS} \mathrm{m}^{-1}$ ), although the growth was reduced when compared with unstressed plants. Saleh (2012) observed that all the cotton cultivars analyzed performed some osmotic adjustment, although the intensity of adjustment was different among them. According to Dong (2012), among the most important mechanisms of $\mathrm{Na}^{+}$exclusion are the extrusion from the cytoplasm and the partitioning within the vacuole. A cotton variety that allocated $\mathrm{Na}^{+}$to the vacuole tolerated very high sodium content in the leaves and 

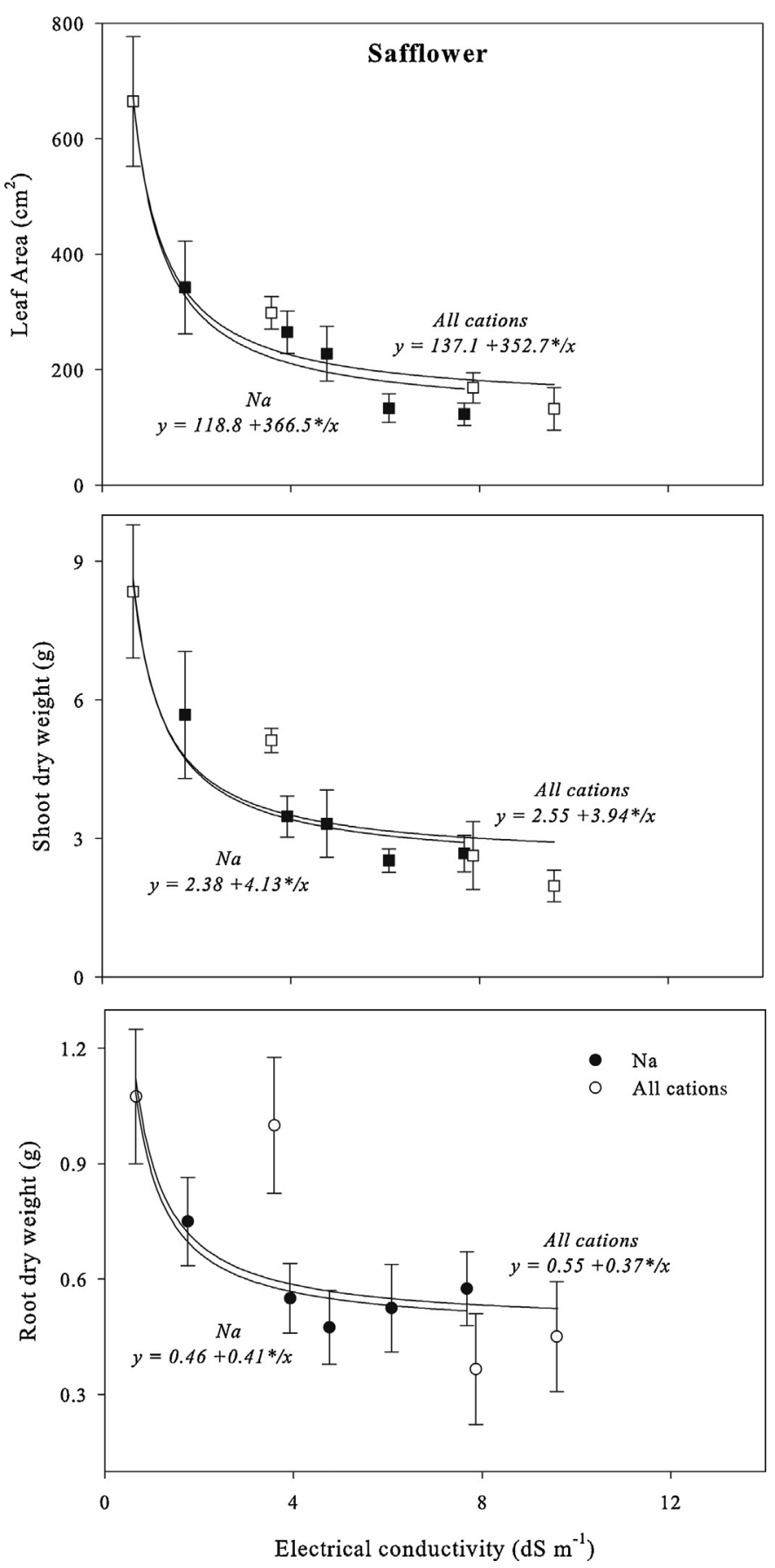

Fig. 4. Effect of the electrical conductivity of the irrigation water containing combinations of $\mathrm{Na}^{+}, \mathrm{Ca}^{2+}$, and $\mathrm{Mg}^{2+}$ on the leaf area, and shoot and root dry weight of 30-days old safflower plants.

was less affected by the increased salinity (Leidi and Saiz, 1997). The tolerance to $\mathrm{Na}^{+}$among cotton varieties was associated with a lower $\mathrm{Na}^{+} / \mathrm{K}^{+}$ratio in the phloem sap (i.e., sodium exclusion in the root) and with a better osmotic adjustment (Qadir and Shams, 1997).

In this experiment, the plants were exposed to the salt stress up to 30 days. Cotton plants are commonly more sensitive during this phase of early growth (Dong, 2012). This is a typical period that plants can sustain growth based on osmotic adjustment (Munns, 2002). If the stress were kept longer than that, ions would accumulate to toxic levels in root, stems, and leaves. Unless the plants were also selected for ionic tolerance, other symptoms would be observed such as slow plant growth and short leaf lifespan. The tolerance at later growth stages can be considerably different from the tolerance observed at seed germination, seedling emergence, and early development (Munns and Tester, 2008; Qadir and Shams, 1997).

Cotton can benefit from breeding for salt tolerance because there is large variability in the response of cotton genotypes to salt stress and medium to high heritability of many characteristics associated with tolerance to salinity (Dong, 2012; Leidi and Saiz, 1997; Qadir and Shams, 1997; Shaheen et al., 2012; Tiwari et al., 2013). The results observed in the present study are evidence that the selection of cotton cultivars should consider the salt composition of the target environment rather than using $\mathrm{NaCl}$ assuming that the selected plants would be broadly tolerant to salinity caused by other salts. Cotton has mechanisms for exclusion of $\mathrm{Na}^{+}$and $\mathrm{Cl}^{-}$ions (Dong, 2012; Munns and Tester, 2008) that are likely ineffective against the salinity caused by different ions.

\subsection{Safflower}

The response of safflower plants to increasing salinity (Fig. 4) was typical of osmotic adjustment, which is able to support plant growth for some weeks (Munns and Tester, 2008). The safflower line 672 apparently had no ion-specific mechanism because the response was explained by the EC of water rather than the salt composition. The tolerance found in some safflower cultivars was attributed to combinations at varying degrees of several physiological mechanisms such as ion-exclusion, osmotic adjustment, accumulation in the vacuole, production of anti-oxidant substances, and ion-tolerance (Kaya et al., 2011; Karray-Bouraoui et al., 2011; Siddiqi et al., 2007, 2011; Siddiqi and Ashraf, 2008).

Similar to what was discussed for cotton, traits associated with salt tolerance in safflower have high heritability (Golkar, 2011), and the tolerance is specific to the conditions that the plant was selected, particularly regarding ion composition. Thus, safflower is regarded as a salt tolerant species, but there is large variability among varieties in this characteristic (Bassil and Kaffka, 2002; Golkar, 2011; Irving et al., 1988; Karray-Bouraoui et al., 2011; Kaya et al., 2011; Siddiqi et al., 2011; Yeilaghi et al., 2012). The line 672 used in this study was not selected under salt stress (but to endure low temperatures during winter), and consequently it showed little tolerance to this stressful condition. In contrast, the seed yield of the cultivar $518 \mathrm{~S}$ was not affected by irrigation water with $\mathrm{EC}=7.13 \mathrm{dS} \mathrm{m}^{-1}$, despite the reduction in total biomass (Bassil and Kaffka, 2002), and many cultivars survived and produced seed when subjected to salinity as high as $12 \mathrm{dS} \mathrm{m}^{-1}$ (Yeilaghi et al., 2012) or $20.5 \mathrm{dS} \mathrm{m}^{-1}$ (Irving et al., 1988).

Opposing to the sensitivity during vegetative growth, the line 672 was tolerant during seedling emergence (Table 3 ). This result is in contrast with the reports that safflower is more sensitive during the phase of seed germination than during vegetative growth (Bassil and Kaffka, 2002; Irving et al., 1988). A clear reduction in germination of safflower seeds at equivalent salinity was observed by Dantas et al. (2011), while the germination of the salt-tolerant cv. Dinçer was not affected up to $30 \mathrm{dS} \mathrm{m}^{-1}$ of $\mathrm{NaCl}$ (Kaya et al., 2011).

The tolerance to salt stress during germination and emergence is not associated with the tolerance during plant growth, and there is significant genetic variability for this trait. This study confirmed that although the seed germination of the line 672 was not affected by $13.7 \mathrm{dS} \mathrm{m}^{-1}$ of salinity, the plants did not survive at salinity higher than $9 \mathrm{dS} \mathrm{m}^{-1}$. Siddiqi et al. (2007) demonstrated that safflower lines had pronounced variability in germination and seedling growth in response to high salinity. 
Table 3

Influence of the salinity of water on the emergence rate and in the time for $40 \%$ emergence of safflower seedlings.

\begin{tabular}{|c|c|c|c|c|c|}
\hline \multicolumn{6}{|c|}{ Safflower } \\
\hline \multicolumn{3}{|c|}{$\mathrm{Na}^{+}$} & \multicolumn{3}{|c|}{$\mathrm{Na}^{+} \mathrm{Ca}^{2+} \mathrm{Mg}^{2+}$} \\
\hline Electrical conductivity $\left(\mathrm{dS} \mathrm{m}^{-1}\right)$ & Emergence (\%) & $\begin{array}{l}\text { Time for } 40 \% \\
\text { emergence (days) }\end{array}$ & $\begin{array}{l}\text { Electrical conductivity } \\
\left(\mathrm{dS} \mathrm{m}^{-1}\right)\end{array}$ & Emergence (\%) & $\begin{array}{l}\text { Time for } 40 \% \\
\text { emergence (days) }\end{array}$ \\
\hline 0.7 & 65.0 & 2.6 & 0.7 & 65.0 & 2.6 \\
\hline 1.8 & 65.0 & 2.6 & 3.6 & 54.44 & 2.6 \\
\hline 3.9 & 61.7 & 2.7 & 7.9 & 70.56 & 3.7 \\
\hline 4.8 & 66.1 & 2.4 & 9.6 & 67.22 & 2.5 \\
\hline 6.1 & 64.4 & 2.5 & 12.8 & 66.11 & 2.5 \\
\hline 7.7 & 56.1 & 3.3 & 13.7 & 56.11 & 2.6 \\
\hline Regression equation & $y=66.8-0.90^{n s} x$ & $y=2.4+0.06^{n s} x$ & & $y=62.9+0.03^{n s} x$ & $y=2.6+0.005^{n s} x$ \\
\hline
\end{tabular}

\subsection{Alleviation of Na-toxicity with addition of $\mathrm{K}^{+}, \mathrm{Ca}^{2+}$, and $\mathrm{Mg}^{2+}$}

The antagonism between $\mathrm{Na}^{+}$and the three cations that are essential nutrients $\left(\mathrm{K}^{+}, \mathrm{Ca}^{2+}\right.$, and $\left.\mathrm{Mg}^{2+}\right)$ is well documented in the literature (Kopittke et al., 2011; Kopittke, 2012; Munns and Tester, 2008; Tester and Davenport, 2003). However, the results of many studies are inconclusive if $\mathrm{Na}^{+}$-toxicity in crops can be alleviated by fertilization with those antagonistic nutrients (Wakeel, 2013). Under saline conditions of the soil, additional $\mathrm{K}^{+}$fertilization sometimes increases crop growth and productivity, increases $\mathrm{K}^{+}$tissue content, and reduces the $\mathrm{Na}^{+}: \mathrm{K}^{+}$ratio. However, in many cases it can also affect negatively or have no effect on crop growth and productivity (Wakeel, 2013). Joshi et al. (2012) observed that castor plants benefited from supplemental $\mathrm{Ca}^{2+}$ in a soil with $4.1 \mathrm{dS} \mathrm{m}^{-1}$ when the $\mathrm{Na}^{+}: \mathrm{Ca}^{+2}$ was raised to $1: 0.25$, but further increments of $\mathrm{Ca}^{+2}$ caused reductions in the seedling emergence and plant growth.

The present study is corroborating with the hypothesis that fertilization with $\mathrm{K}^{+}, \mathrm{Ca}^{2+}$, and $\mathrm{Mg}^{2+}$ have a real but limited capacity of $\mathrm{Na}$-toxicity alleviation in the plant growth. In the one hand, the beneficial effect can be associated with both the antagonism with $\mathrm{Na}^{+}$ and an improvement in the nutritional status of the plant (when the nutrients supply is above plant requirements). In the other hand, the addition of fertilizers to a salinized soil can increase the electrical conductivity and aggravate the salt stress. It seems that finding a balance between those contrasting effects is not an easy task at field conditions.

\section{Conclusions}

The presence of calcium and magnesium in the irrigation water did not alleviate the toxic effect of sodium on the emergence and initial growth of castor, cotton, and safflower plants. Reflecting the selection of the varieties used in this study, the response of castor and safflower to increased salinity was associated with the electrical conductivity of the water rather than by the salt composition, while cotton was tolerant to $\mathrm{Na}^{+}$, but sensitive to $\mathrm{Ca}^{2+}$ and $\mathrm{Mg}^{2+}$.

\section{Acknowledgments}

To Dr. Hans R. Gheyi for the critical review of the manuscript, and to CNPq for the PNPD grants to the second and fourth authors.

\section{References}

Auld, D.L., Pinkerton, S.D., Boroda, E., Lombard, K.A., Murphy, C.K., Kenworthy, K.E., Becker, W.D., Rolfe, R.D., Ghetie, V., 2003. Registration of TTU-LRC castor germplasm with reduced levels of ricin and RCA-120. Crop Sci. 43, 746-747.

Ashraf, M., Foolad, M.R., 2005. Pre-sowing seed treatment-a shotgun approach to improve germination, plant growth, and crop yield under saline and non-saline conditions. Adv. Agron. 88, 223-271.
Ashworth, J.B., 1995. Ground water resources of the Bone Spring - Victorio Peak aquifer in the Dell Valley area, Texas. Texas Water Development Board, Austin, TX (Report 344).

Bassil, E.S., Kaffka, S.R., 2002. Response of safflower (Carthamus tinctorius L.) to saline soils and irrigation II. Crop response to salinity. Agric. Water Manage. 54, 81-92.

Ben-Gal, A., Borochov-Neori, H., Yermiyahu, U., Shani, U., 2009. Is osmotic potential a more appropriate property than electrical conductivity for evaluating wholeplant response to salinity? Environ. Exp. Bot. 65, 232-237.

Castillo, N., 2011. A hydroponic approach to evaluate responses to salinity stress in cotton. In: Ph.D. Dissertation. Texas Tech University, Lubbock, TX.

Costa, M.E., Morais, F.A., Souza, W.C.M., Gurgel, M.T., Oliveira, F.H.T., 2013. Irrigation strategies with saline water in castor oil plant. Revista Ciência Agronômica 44, 34-43.

Dantas, C.V.S., Silva, I.B., Pereira, G.M., Maia, J.M., Lima, J.P.M.S., Macedo, C.E.C., 2011 Influence of salinity and water deficit on the germination of Carthamus tinctorius L seeds. Revista Brasileira de Sementes 33, 574-582.

Dong, H., 2012. Technology and field management for controlling soil salinity effects on cotton. Aust. J. Crop Sci. 6, 333-341.

Golkar, P., 2011. Inheritance for salt tolerance in safflower (Carthamus tinctorius L.) Adv. Environ. Biol. 5, 3694-3699.

Grattan, S.R., Grieve, C.M., 1999. Salinity-mineral nutrients relations in horticultura crops. Sci. Hortic. 78, 127-157.

Graybill, F.A., 1976. Theory and Application of the Linear Model. Wadsworth and Brooks/Cole, Pacific Grove, CA.

Irving, D.W., Shannon, M.C., Breda, V.A., Mackey, B.E., 1988. Salinity effects on yield and oil quality of high-linoleate and high-oleate cultivars of safflower (Carthamus tinctorius L.). J. Agric. Food Chem. 36, 37-42.

Joshi, S.V., Patel, N.T., Pandey, I.B., Pandey, A.N., 2012. Effect of supplemental $\mathrm{Ca}^{2+}$ on NaCl-stressed castor plants (Ricinus communnis L.). Acta Bot. Croat. 71, 13-29.

Karray-Bouraoui, N., Harbaoui, F., Rabhi, M., Jallali, I., Ksouri, R., Attia, H., Msilini, N., Lachaâl, M., 2011. Different anti-oxidant responses to salt stress in two different provenances of Carthamus tinctorius L. Acta Physiol. Plant. 33, 1435-1444.

Kaya, M.D., Bayramin, S., Kaya, G., Uzun, O., 2011. Seed vigor and ion toxicity in safflower (Carthamus tinctorius L.) seedlings produced by various seed sizes under $\mathrm{NaCl}$ stress. Arch. Biol. Sci. 63, 723-729.

Kopittke, P.M., Blamey, F.P., Kinraide, T.B., Wang, P., Reichman, S.M., Menzies, N.W. 2011. Separating multiple, short-term, deleterious effects of saline solutions on the growth of cowpea seedlings. New Phytol. 189, 1110-1121.

Kopittke, P.M., 2012. Interactions between Ca, Mg, Na and K: alleviation of toxicity in saline solutions. Plant Soil 352, 353-362.

Leidi, E.O., Saiz, J.F., 1997. Is salinity tolerance related to Na accumulation in upland cotton (Gossypium hirsutum) seedlings? Plant Soil 190, 67-75.

Li, G., Wanb, S., Zhoua, J., Yanga, Z., Qina, P., 2010a. Leaf chlorophyll fluorescence, hyperspectral reflectance, pigments content, malondialdehyde and proline accumulation responses of castor bean (Ricinus communis L.) seedlings to salt stress levels. Ind. Crops Prod. 31, 13-19.

Li, Z., Li, G., Qin, P., 2010b. The prediction of ecological potential for developing salttolerant oil plants on coastal saline land in Sheyang Saltern, China. Ecol. Eng. 36, 27-35.

Munns, R., 2002. Comparative physiology of salt and water stress. Plant Cell Environ. 25, 239-250.

Munns, R., Tester, M., 2008. Mechanisms of salinity tolerance. Annu. Rev. Plant Biol. 59, 651-681.

Nobre, R.G., Lima, G.S., Gheyi, H.R., Lourenço, G.S., Soares, L.A.A., 2013. Emergence, growth and production of the castor bean under saline stress and nitrogen fertilization. Revista Ciência Agronômica 44, 76-85.

Oswalt, J.S., Auld, D.L., 2011. Development of safflower as a new winter crop for the Texas High Plains. In: ASA International Annual Meetings, San Antonio, TX, 2011, Available at /http://a-c-s.confex.com/crops/2011am/webprogram/ Paper67079.html $>$.

Pinheiro, H.A., Silva, J.V., Endres, L., Ferreira, V.M., Camara, C.A., Cabral, F.F., et al., 2008. Leaf gas exchange, chloroplastic pigments and dry matter accumulation in castor bean (Ricinus communis L) seedlings subjected to salt stress conditions. Ind. Crops Prod. 27, 385-392.

Plaza, B.M., Jiménez, S., Lao, M.T., 2012. Influence of salt stress on the nutritional state of Cordyline fruticosa var. Red Edge, 2: sodium, potassium, calcium, and magnesium. Commun. Soil Sci. Plant Anal. 43, 234-242. 
Qadir, M., Shams, M., 1997. Some agronomical and physiological aspects of salt tolerance in cotton (Gossypium hirsutum L.). J. Agron. Crop Sci. 179, 101-106.

Rahimi, A., 2013. Seed priming improves the germination performance of cumin (Cuminum syminum L.) under temperature and water stress. Ind. Crops Prod. 42, 454-460.

Saleh, B., 2012. Salt stress alters physiological indicators in cotton (Gossypium hirsutum L.). Soil Environ. 31, 113-118.

Severino, L.S., Auld, D.L., Baldanzi, M., Cândido, M.J.D., Chen, G., Crosby, W., et al., 2012a. A review on the challenges for increased production of castor. Agron. J. $104,853-880$.

Severino, L.S., Cordoba, G.O.J., Zanotto, M.D., Auld, D.L., 2012b. The influence of the caruncle on the germination of castor seed under high salinity or low soil water content. Seed Sci. Technol. 40, 140-144.

Shaheen, H.L., Shahbaz, M., Ullah, I., Iqbal, M.Z., 2012. Morpho-physiological responses of cotton (Gossypium hirsutum) to salt stress. Int. J. Agric. Biol. 14, 980-984.

Siddiqi, E.H., Ashraf, M., 2008. Can leaf water relation parameters be used as selection criteria for salt tolerance in safflower (Carthamus tinctorius L.)? Pak. J. Bot. 40, $221-228$.

Siddiqi, E.H., Ashraf, M., Akram, N.A., 2007. Variation in seed germination and seedling growth in some diverse lines of safflower (Carthamus tinctorius L.) under salt stress. Pak. J. Bot. 39, 1937-1944.

Siddiqi, E.H., Ashraf, M., Al-Qurainy, F., Akram, N.A., 2011. Salt-induced modulation in inorganic nutrients, antioxidant enzymes, proline content and seed oil composition in safflower (Carthamus tinctorius L.). J. Sci. Food Agric. 91, 2785-2793.
Silva, S.M.S., Alves, A.N., Gheyi, H.R., Beltrão, N.E.M., Severino, L.S., Soares, F.A.L. 2005. Germination and initial growth of two cultivars of castor bean under saline stress. Revista Brasileira de Engenharia Agrícola e Ambiental supplement, 347-352.

Silva, S.M.S., Alves, A.N., Ghey, H.R., Beltrão, N.E.M., Severino, L.S., Soares, F.A.L., 2008. Growth and production of two cultivars of castor bean under saline stress. Revista Brasileira de Engenharia Agrícola e Ambiental 12, 335-342.

Sun, Y., Niu, G., Osuna, P., Ganjegunte, G., Auld, D., Zhao, L., Peralta-Videa, J.R., GardeaTorresdey, J.L., 2013. Seedling emergence, growth, and leaf mineral nutrition of Ricinus communis L. cultivars irrigated with saline solution. Ind. Crops Prod. 49 75-80.

Tester, M., Davenport, R., 2003. $\mathrm{Na}^{+}$tolerance and $\mathrm{Na}^{+}$transport in higher plants. Ann. Bot. 91, 503-527.

Tiwari, R.S., Picchioni, G.A., Steiner, R.L., Jones, D.C., Hughs, S.E., Zhang, J., 2013. Genetic variation in salt tolerance at the seedling stage in an interspecific backcross inbred line population of cultivated tetraploid cotton. Euphytica, http://dx.doi.org/10.1007/s10681-013-0927-x.

Wakeel, A., 2013. Potassium-sodium interactions in soil and plant under saline-sodic conditions. J. Plant Nutr. Soil Sci. 176, 344-354, http://dx.doi.org/10.1002/jpln.201200417.

Yeilaghi, H., Arzani, A., Ghaderian, M., Fotovat, R., Feizi, M., Pourdad, S.S., 2012. Effect of salinity on seed oil content and fatty acid composition of safflower (Carthamus tinctorius L.) genotypes. Food Chem. 130, 618-625.

Zhou, G., Ma, B.L., Li, J., Feng, C., Lu, J., Qin, P., 2010. Determining salinity threshold level for castor bean emergence and stand establishment. Crop Sci. 50 2030-2036. 